\title{
INTERNET KAO VAŽAN SEGMENT INFORMACIONO-KOMUNIKACIONIH TEHNOLOGIJA PRILIKOM UČENJA I U NASTAVI ENGLESKOG JEZIKA
}

\begin{abstract}
Rezime: Cilj rada je da utvrdi stepen upotrebe interneta (važnog segmenta informaciono-komunikacionih tehnologija) kao sredstva za učenje i poučavanje na srednjoškolskom nivou. Sprovedeno je istraživanje među učenicima prve, druge, treće i četvrte godine Gimnazije i tehničke škole „Kosovska Mitrovica”. U skladu sa ciljem istraživanja, korištena je deskriptivna metoda. Analizom rezultata došlo se do zaključka da se internet $\mathrm{i}$ jedan od najpoznatijih veb-sajtova na internetu, Jutjub (YouTube), u velikoj meri koriste među učenicima srednjoškolskog uzrasta, premda ne uvek i ne najčešće za učenje jezika. Učenici u velikoj meri zavise od ove tehnologije, iako se još uvek u potpunosti ne oslanjaju na nju kada je u pitanju ovladavanje školskim gradivom. Ipak, istraživanje je pokazalo da većina njih smatra da bi ona bila od velike koristi za nastavni proces i proces učenja, ali i da njihovi nastavnici retko koriste internet kao nastavno sredstvo.
\end{abstract}

Ključne reči: informaciono-komunikacione tehnologije, internet, samoregulisano učenje, engleski jezik.

\section{ZNAČAJ INFORMACIONO-KOMUNIKACIONIH TEHNOLOGIJA I INTERNETA ZA PROCES SAVREMENOG OBRAZOVANJA}

Značaj informaciono-komunikacionih tehnologija (ako drukčije nije naglašeno, u daljem tekstu: IKT) za proces učenja i obrazovanja se u poslednje vreme sve češće ističe. Još 2008. godine se u izveštaju Evropske komisije (Commission of the European communities, 2008) isticala važnost IKT-a za obrazovni proces koji bi se uvođenjem ovih tehnologija mogao osavremeniti i „osvežiti”. I u našoj zemlji, inicijative za razvoj i implementaciju obrazovnih tehnologija u nastavi pokreću se na republičkom nivou i nastoji se na što bržem i potpunijem njihovom integrisanju u obrazovni proces. Posebno se ističu sledeći ciljevi: uvođenje savremenog koncepta e-učenja i učenja na daljinu, kao i razvoj digitalnih obrazovnih sadržaja, što bi skupa dovelo do uspostavljanja modernog obrazovnog sistema koji je prilagođen potrebama informacionog društva (Marković Blagojević, Aćimović i Karavelić, 2017: 52). 
Značaj integracije IKT-a u obrazovanje ističe i Nacionalni prosvetni savez Republike Srbije (NPS) u svojim Smernicama za unapređivanje uloge informaciono-komunikacionih tehnologija u obrazovanju (2013: 19), ukazujući na njihovu multidisciplinarnost i primenjivost na sve segmente obrazovanja, od kojih je za nas od posebnog interesa nastava jezika - konkretno engleskog jezika. Ipak, realizovanje ovog procesa nije sasvim jednostavno budući da je, naglašava NPS, primena IKT-a u nastavi i učenju izuzetno široka oblast koja obuhvata „najrazličitije aspekte upotrebe savremenih tehnologija i softvera u sistemu osnovnog i srednjeg obrazovanja" (NPS, 2013: 45). lako svaki od ovih aspekata ima svoj značaj, istraživanje svakog ponaosob rezultovalo bi preobimnim istraživanjem, te smo se pri odabiru teme rada morali ograničiti. Pre svega, fokusirali smo se na tehnologije koje podrazumevaju upotrebu računara i, još važnije, interneta, koje autori (kao Tomlison i Harmer) često ističu veoma praktične i pogodne za učenje i nastavu jezika (što je glavni domen našeg interesovanja).

Harmer (2007), na primer, smatra da je računar izuzetno pogodan za obavljanje jezičkih vežbi i tvrdi da jezičke vežbe obavljene na računaru pospešuju razvoj timskog duha i saradnju među učenicima. Računar je, uopšte, pogodan za „brzo i lako pronalaženje korisnih i prikladnih digitalnih materijala", smatra Tomlison, što nesumnjivo olakšava posao nastavnika. Treba naglasiti da se ovakvi materijali mogu koristiti kako za potrebe nastave različitih predmeta, tako i u toku samostalnog učenja (Tomlison, prema Ahmadi, 2018) i uglavnom se mogu pronaći upravo na internetu. Uz to, ovi i mnogi drugi autori (Bhakta \& Dutta, 2016; Passey, Rogers, Machell \& McHugh, 2004; Mandić, 2009) veruju da digitalni materijali uz upotrebu interneta pozitivno utiču na motivaciju učenika za rad, unoseći tehnologiju kao deo njihove svakodnevnice u proces učenja.

\subsection{Informaciono-komunikacione tehnologije (IKT) i samoregulisano učenje}

Pomenuli smo samostalno učenje - u literaturi poznatije kao samoregulisano učenje - na kome se sve češće insistira u kontekstu savremenog obrazovanja. Ovaj vid učenja predstavlja „aktivan, konstruktivan proces u kome ciljeve postavlja učenik koji prati i kontroliše svoju motivaciju, ponašanje, saznavanje i proces učenja uopšte|" (Pintrich, 1995). Dakle, glavni cilj samoregulisanog učenja je, pre svega, samostalno istraživanje i proširivanje znanja učenika, uz povećanu dozu slobode i integriteta kada je u pitanju oblikovanje samog procesa učenja (Lončarić, 2014). Ovde je važno naglasiti istraživanje naspram pamćenja činjenica, na kojima se insistira u okviru formalnog procesa obrazovanja. Nadalje, autori smatraju da samoregulisano učenje povećava nivo motivacije učenika, osamostaljuje ih i omogućava da u skladu sa svojim mogućnostima i željama isplaniraju vreme, organizaciju radne sredine i strategiju učenja (ibidem, 282). Ovo se učenje često dovodi u spregu sa informaciono-komunikacionim tehnologijama (Dresel \& Handel, 2008) budući da upotreba računara, a pogotovu interneta, omogućava da se realizuju gore pomenuti zadaci samoregulisanog učenja. Pre svega, računari omogućavaju određivanje tempa, trajanje i zahtevnost procesa učenja, zatim dozvoljavaju da se češće vežba i utvrđuje naučeno, pružaju stalni uvid u napredak učenika i, na kraju, nude mogućnost evaluacije učenika koja se može odvijati „na daljinu”, bez nužnog prisustva nastavnika. Pored ovoga, oni i pozitivno utiču na motivaciju učenika koji sami biraju ono što će učiti u skladu sa svojim interesima, potrebama i afinitetima (Klimova, 2012: 197). Samoregulisano učenje, zaključujemo, može se u potpunosti sprovesti putem računara i interneta, izuzetno korisnih medija IKT-a. Na kraju, sugerisali bismo i da samoregulisano učenje zajedno sa upotrebom pomenutih savremenih tehnologija može pomoći da se prevaziđu osnovni nedostaci klasičnog (tradicionalnog) pristupa nastavi koji je još uvek široko 
rasprostranjen, a koji je postao „potpuno neprimeren svetu oko njega” (Eleven i Glušac, 2008: 398).

\subsection{Nužnost uvođenja informaciono-komunikacionih tehnologija (IKT-a) u nastavni proces i proces učenja - neadekvatnost tradicionalnog pristupa}

Nedostatnost tradicionalnog pristupa u odnosu na potrebe savremenog društva i, nasuprot njoj, adekvatnost primene računara, interneta i samoregulisanog učenja možemo opaziti u sledećoj tabeli (Tabela 1) koju su dale Eleven i Glušac (ibidem, 399).

Tabela 1. Odnos između tradicionalnog pristupa u nastavi i potreba savremenog društva (prema Eleven \& Glušac, 2008)

\begin{tabular}{|c|c|c|c|}
\hline 1. & Tradicionalni pristup & 2. & Potrebe \\
\hline a) & Činjenice & a) & Rešavanje problema \\
\hline b) & Individualan rad & b) & Timski rad \\
\hline c) & Prolaženje testova & c) & Znati kako učiti \\
\hline d) & Deljenje znanja na područja & d) & Interdisciplinarno znanje \\
\hline e) & Primanje informacija & e) & Interakcija i proučavanje informacija \\
\hline f) & $\begin{array}{l}\text { Tehnologija odvojena od } \\
\text { učenja }\end{array}$ & f) & Tehnologija integrisana u proces učenja i rada \\
\hline
\end{tabular}

Iz Tabele 1 se jasno vide domeni u kojima tradicionalna nastava zaostaje u odnosu na modernizovanu nastavu, obogaćenu IKT-om. Dok pređašnja nudi mogućnost usvajanja činjenica, nastava u koju su integrisane digitalne tehnologije nudi učenicima mogućnost da nauče kako da rešavaju probleme. IKT takođe pospešuju i timski rad, navodi Klimova (2016), koji je još jedan od zahteva savremenog obrazovanja, dok se u tradicionalnoj nastavi vrednuje individualni rad i podstiče takmičarski duh (obrazuju se grupe koje se međusobno takmiče, radi se samostalno ili u paru, a odeljenje kao grupa retko sarađuje). Takođe, kod samoregulisanog učenja, kako učenici najčešće nemaju nastavnike kao vodiče, sami usvajaju gradivo te se podrazumeva da u tom procesu oni i „uče kako treba učiti”. Poslednju stavku koja se tiče potreba savremenog obrazovanja nije neophodno obrazlagati; IKT ne samo da se uklapaju u moderan nastavni proces, već čine i neizostavni njego deo.

Zašto onda i pored svih prednosti IKT-a tradicionalne metode nastave još uvek preovladavaju? Zašto se još uvek u našim školama izvodi nastava koja već odavno nije podobna za savremeno društvo koje se sve brže razvija?

Kao odgovor navodimo reči Nadrljanskog, koji govori o inertnosti škole koja je „po prirodi konzervativna institucija”, i njenoj nevoljnosti da bilo šta promeni istakavši da ona „dugo zadržava određene obrazovne modele rada koji su davno zastarjeli”. Sa ove tačke gledišta on o informatizaciji škole govori kao o narušavanju njene statičnosti, podsećajući na činjenicu da nova praksa, nažalost, u školu teško ulazi - iako se ona, jednom kad je prihvati, teško nje oslobađa. Na kraju zaključuje da je mirnim, statičnim školama ipak došao kraj.

Iz ovih razloga brojni autori (Mandić, 2003; Nadrljanski, 2006; Stanković, 2012; Klarić, 2009) nastavljaju da insistiraju na nužnosti uvođenja IKT-a u nastavu. Arsović (prema Jovanović, 2014: 114) zagovara potrebu da se sadašnje nastavne i metode učenja zamene novim. Jovanović dodaje da bismo barem mogli model tradicionalne nastave da obogatimo novim ,sredstvima, tehnologijama, medijima, metodama i putevima komunikacija” pomoću implementacije $\mathbf{i}$ 
pravilnog korišćenja dostignuća iz oblasti savremene informacione tehnologije, ukoliko se on već ne može u potpunosti zameniti (Jovanović, 2010: 45).

Kako smo izložili teorijsku osnovu primene IKT-a na proces učenja (samoregulisanog) i nastavni proces, u narednom delu rada izložićemo kratko osobine učenika/srednjoškolaca kao adolescenata i kao internet-korisnika tzv. net-generacije, u odnosu na koje smo u ovom radu posmatrali pomenute koncepte.

\subsection{Srednjoškolci, adolescenti, internet korisnici}

Učenici srednje škole prolaze kroz fazu adolescencije - period turbulentnih psihičkih i fizičkih promena u životu svakog pojedinca. Karakterišu ga nagli intelektualni razvoj, povišena emocionalnost, osetljivost i nesigurnost (Montero, 2018: 65-66). Iz ovih i sličnih razloga se ova uzrasna grupa često smatra problematičnom, te grupom koja za nastavnike predstavlja naročiti izazov kada je u pitanju postizanje i održavanje željenog nivoa discipline i motivacije. U radu sa ovom grupom autoritet nastavnika značajno opada, budući da u ovoj fazi razvoja nastavničko odobravanje više nije od presudnog značaja za učenike (Harmer, 2007: 84), utoliko više što današnji adolescenti ne smatraju nastavnika i udžbenik jedinim izvorom informacija; danas se oni u znatno većoj meri oslanjaju na računar i informacije koje su im dostupne na internetu (Golijanin i sar., 2014). Iz ovog razloga se sadašnji učenici srednje škole (rođeni u periodu od 2001. do 2004. godine) u literaturi često nazivaju net- generacijom, digitalnom generacijom, Generacijom Z ili postmilenijalcima (Tapavički Duronjić, 2011; Golijanin i

sar., 2014). Rođeni u jeku naučno-tehnološke revolucije, postmilenijalci su od ranog detinjstva učeni da se oslanjaju na „,blagodeti” tehnologije, stoga je, rekli bismo, razumljivo da aktuelni oblik organizacije nastave kod učenika, koji putem interneta imaju brz i neograničen pristup svemu što žele da nauče, ima za posledicu nezainteresovanost i pasivnost (Golijanin i sar., 2014). Kako smatraju Golijanin i saradnici, ovaj vid nastave ograničava učenike jer zahteva puko usvajanje i reprodukovanje gotovih, unapred pripremljenih informacija (autori ga opisuju kao „algoritam sa krajnjim ciljem pamćenja informacija” (ibidem, 2014).

Iz ovih razloga oni insistiraju na inoviranju nastave i upozoravaju na nužnost ulaganja napora od strane nastavnika da razumeju tehnologije kojima se njihovi učenici služe, njihov uticaj na tinejdžere i dodaju da nastavnici moraju nastojati da i sami ovladaju njima. Smatramo da ova povezanost nesumnjivo iziskuje da se ovaj važni deo svakodnevnice učenika uključi i u njihovo obrazovanje.

\section{INTERNET PRILIKOM UČENJA I U NASTAVI ENGLESKOG JEZIKA}

Internet je danas svetski poznata pojava čiji se spektar primene povećava iz dan u dan. To je „komunikaciona tehnologija koju koristi skoro dve milijarde ljudi širom sveta i bez koje bi život kakav danas poznajemo bio nemoguć" (Vasić, 2010). Milioni ljudi svakodnevno komuniciraju zahvaljujući internetu; razmenjuju se ideje, informacije, dokumenti. Cela planeta je na vrhovima naših prstiju (Milošević, Kontrec i Đošić, 2013). Internet, u suštini, predstavlja jednu veliku bazu znanja. Mogućnosti njegove primene su bezbrojne - putem interneta ljudi se informišu, uče, komuniciraju, kupuju, apliciraju za poslove, škole, fakultete; uopšte, moglo bi se reći da se svaki aspekt života može urediti i usmeriti pomoću interneta.

Široka rasprostranjenost interneta dodatno pospešuje njegovu popularnost budući da mu se može pristupiti gotovo bilo kada i bilo gde. Ovo svojstvo interneta ističe se kao jedna od 
najvažnijih prednosti njegovog korišćenja - zahvaljujući internetu „ljudi iz prakse dele svoja iskustva i uče jedni od drugih" (Kern, 2013: 112).

Posmatrano sa aspekta obrazovanja, koje je naš predmet interesovanja, mora se istaći veliki obrazovni potencijal interneta kao baze znanja kojoj se može lako i brzo pristupiti kako bi se pronašle potrebne informacije. Budući da smo već ukazali na to da razvoj IKT-a uslovljava promene i inovacije u obrazovanju, metodama i oblicima nastavnog rada (Mandić, 2009) i da se sve češće govori o neophodnosti uvođenja IKT-a u nastavu, kako opštih i stručnih predmeta, tako i u nastavu stranih jezika (Radić Branisavljević i Milovanović, 2014: 500), u narednom delu rada razmatraćemo ulogu interneta, kao važnog segmenta IKT-a za učenje i u nastavi engleskog jezika. Pažnju ćemo posvetiti i jednom od najpopularnijih veb-sajtova, Jutjubu (YouTube), koji se koristi u gotovo istoj meri kao i sam internet, a čiju su korisnost za nastavu već istakli brojni autori.

Da bi se ovladalo stranim jezikom, neophodno je ovladati četirima veštinama, smatraju Radić Branisavljević i Milovanović (2014). Četiri jezičke veštine koje treba vežbati prilikom učenja stranog jezika su: govor i pisanje, koje su aktivne jezičke veštine i slušanje i čitanje, koje spadaju u pasivne jezičke veštine (2014: 500). Ove veštine se još u literaturi pominju i kao produktivne i receptivne veštine ${ }^{2}$ (Harmer, 2007; Krashen, 1987; Nunan, 2003). Za vežbanje pomenutih veština autorke predlažu upravo internet kao pogodan, bogat i lako dostupan izvor materijala za učenje jezika, zajedno sa Jutjubom ${ }^{3}$, za koga smo već naglasili da je izuzetno popularan i često korišten. Smatrajući ih izuzetno pogodnim medijima za učenje, autorke predlažu različite načine na koje bi se, pomoću ova dva medija, mogle vežbati sve četiri jezičke veštine, a koji bi učenici mogli koristiti u školi i van škole, po sopstvenom nahođenju i u skladu sa svojim afinitetima.

Veština govora se do sada uglavnom vežbala ,tako što bi profesor zadao određenu temu, a đaci bi održavali neki vid komunikacije" (2014: 501). Ipak, ovakva komunikacija je bila daleko od spontane, prirodne komunikacije, a učenici su neretko imali poteškoća kada bi se govorilo o njima nepoznatoj ili neinteresantnoj temi. Radić Branisavljević i Milovanović predlažu za razvoj ove veštine vežbe poput pevanja, recitovanja ili glume na nekom stranom jeziku. Odgovarajući materijali za vežbanje, predlažu autorke, mogli bi se lako (i besplatno) naći na internetu, odnosno Jutjubu. Učenicima se na Jutjubu može pustiti adekvatan spot pesme, a potom se oni mogu „motivisati da pevaju sa svojim omiljenim izvođačem” (ibidem). Osim Jutjuba, za vežbanje veštine govora na stranom jeziku mogu se koristiti i drugi veb-sajtovi i vidovi IKT-a. Autorke u ovu svrhu predlažu Skajp (Skype) ${ }^{4}$, pomoću koga učenici mogu „komunicirati sa vršnjacima iz zemlje čiji se jezik uči” ili čak dobijati časove jezika.

Za vežbanje veštine pisanja, autorke predlažu takođe internet i savetuju učenike da pišu mejlove ili ćaskaju u onlajn čet-sobama sa govornicima jezika koji žele da nauče i na taj način

\footnotetext{
${ }^{2}$ engl. productive and receptive skills (Nunan, 2003)

${ }^{3}$ Jutjub je treći najpopularniji veb-sajt na internetu. Služi za deljenje i distribuciju video-sadržaja; često se ističe mogućnost primene Jutjuba u nastavi i pri učenju engleskog jezika, zahvaljujući velikom broju videolekcija vezanih za različite oblasti nauke i kulture (Lance \& Kitchin, 2007).

${ }^{4}$ Skajp je popularna aplikacija koja omogućava besplatno slanje poruka i upućivanje video-poziva putem interneta.
} 
unaprede svoje sposobnosti pisanja na stranom jeziku. I za vežbanje receptivnih, ili kako ih autorke nazivaju, pasivnih, veština one predlažu isto sredstvo. Slušanje se, ističu autorke „može razvijati slušanjem muzike, gledanjem televizije ili filmova na stranom jeziku” (Radić Branisavljević i Milovanović, 2014: 501). Za razvoj ove jezičke veštine efikasni su i diktati, ali i vežbanja sa audio ili video zapisom koji treba preslušati, a zatim uraditi određene zadatke. „I za razvoj jezičke veštine čitanja, potrebno je čitati tekstove i odlomke na stranom jeziku, a zatim raditi vežbanja i odgovarati na pitanja", veruju Radić Branisavljević i Milovanović, ističući ponovo praktičnost upotrebe interneta i veb-sajtova kao što je Jutjub za ovu svrhu.

Dodali bismo i da se, pomoću interneta mogu ne samo vežbati sve četiri jezičke veštine, već bi se moglo i ovladati jezičkim sistemima ${ }^{5}$ praćenjem sadržaja na stranom jeziku koji želimo da naučimo, upotrebom video-lekcija i pohađanjem onlajn kurseva jezika. Informisanje o kulturi i dešavanjima unutar zajednice govornika stranog jezika dodatno doprinosi ovom procesu jer omogućava bliski kontakt sa jezikom koga ovi elementi oblikuju.

\subsection{Problemi i nedostaci informaciono-komunikacionih tehmologija (IKT-a)}

I pored svih navedenih dobrobiti, internet i IKT se u nastavi još uvek malo koriste. Tamo gde se upotrebljavaju, tvrdi Stanković, koriste se više za pripremu časova nego u samoj nastavi, dodaje Stanković zaključujući da je upotreba ove i sličnih tehnologija u nastavi zanemarljiva (Stanković, 2012: 159). Stav ovog i brojnih drugih autora je da se slaba zastupljenost IKT-a u nastavi može delom objasniti nerazvijenošću digitalnih kompetencija nastavnika (Krželj i Polovina, 2019: 118). Zbog nerazumevanja potencijala i značaja tehnologije, kod nastavnika se javlja otpor prema njima te, kako Stanković zapaža, veoma mali broj nastavnika danas prati inovacije na polju obrazovne tehnologije, a određeni broj njih „u prosveti uopšte i ne koristi internet mrežu" (ibidem).

Pod pomenutim terminom, digitalna kompetencija, Krželj i Polovina podrazumevaju „sigurnu i kritičku upotrebu informaciono-komunikacionih tehnologija". Razvijanju ove kompetencije, smatraju autorke, doprinosi uključivanje i ,,angažovanje u mrežama okupljenim oko kulturnih, socijalnih i profesionalnih ciljeva" (2019: 118), pri čemu se mora očuvati kritički stav prema informacijama koje su dostupne. Nastavnik, dakle, mora pristupati ovim informacijama odgovorno i obazrivo i mora nastojati da odvoji korisno od nekorisnog, prikladno od neprikladnog, što u eri „,informacione eksplozije” nije nimalo lak zadatak (Danilović i Danilović, 2012). Stav je autorki da, premda digitalne kompetencije sve više postaju kompetencije od ključnog značaja koje prožimaju sve sfere života, njihova implementacija u svakodnevnu praksu nastavnika, u studijske programe, kurikulume, planove i programe rada u školama još uvek nije na zadovoljavajućem nivou (2019: 118-119).

Sa ovim u vezi, Petrović (2016), koja takođe uviđa nužnost usvajanja informatičkog znanja, upozorava na činjenicu da su hiljade prosvetnih radnika završili svoje obrazovanje pre nego što su se pojavile savremene informaciono-komunikacione tehnologije i da se sada nasuprot njima

${ }^{5} \mathrm{U}$ literaturi se razlikuju četiri jezička sistema: gramatika, vokabular, fonologija i diskurs. Učenje jezika podrazumeva ovladavanje svakim od ovih sistema, zajedno sa pomenutim jezičkim veštinama (Harmer, 2007). 
nalaze „učenici koji su rođeni u digitalnom okruženju i koji se u njemu snalaze veoma lako”, što dodatno produbljuje jaz među generacijama (2016: 17). Petrović ovde upotrebljava termin „digitalni jaz”, navodeći da slabe informatičke kompetencije nastavnika, koje nisu usklađene sa zahtevima učenika i savremene škole, dovode do toga da je učenicima na časovima dosadno, da ne prihvataju nastavnika kao autoritet i da, prosto, ne žele da uče. Ipak, da bismo izbegli generalizaciju, ne smemo tvrditi da svi nastavnici gaje otpor prema ovim tehnologijama. Stanković primećuje da postoje i oni koji nastoje da idu u korak s vremenom, te se obučavaju samostalno, iz stručne literature ili uz pomoć iskusnijih kolega i prijatelja (Stanković, 2012: 159). Ovakvi napori su svakako pohvalni, ali oni sami nisu dovoljni.

Danimir Mandić (citiran u Petrović, 2016) ukazuje na činjenicu da uvođenje nove pedagoške tehnologije podrazumeva ulaganje posebnih napora u prilagođavanje novim načinima rada; ono zahteva dokvalifikaciju, prekvalifikaciju i „,permanentno stručno usavršavanje nastavnika” (2016: 19). Nažalost, zaključuje autor, nastavnici nisu uvek radi da prihvate ovakvu vrstu obaveza - što ne bi trebalo zameriti - budući da je uloga nastavnika danas složenija nego ikad pre.

Jelena Maksimović ovo na živopisan način dočarava tvrdeći da se od savremenog nastavnika danas očekuje da bude „istraživač, programer, organizator rada, savetodavac, pedagoški dijagnostičar, terapeut, vaspitač generacije” (Maksimović, 2012: 17). I ona, kao i Mandić, zaključuje da je ovo moguće postići ,,samo stalnim stručnim usavršavanjem i metodološkim i statističkim obrazovanjem" (ibidem).

Nezavisno od kompetencija nastavnika, uočeni su i drugi problemi kao mogući uzroci zaziranja od upotrebe IKT-a (pogotovo od upotrebe interneta). lako nude brojne olakšice u učenju jezika, pomenuti mediji sadrže i potencijalne opasnosti. „Uočeni nedostaci su uglavnom koncentrisani oko problema socijalne interakcije i bezbednosnih pitanja, oko problema motivacije učenika, itd. (Grainger \& Tolhurst, prema Ranđelović, 2018). Pitanje bezbednosti učenika na internetu otvara naročito osetljive teme, jer dostupnost internet sadržaja ne samo da otvara vrata učenicima ka informacijama i znanjima, već i njih same čini ranjivim, budući da postaju lake mete nepoželjnih sadržaja.

\subsection{Metodološki okvir}

Cilj istraživanja je da se utvrdi u kojoj meri se internet upotrebljava u srednjim školama kao sredstvo za učenje i poučavanje.

Za potrebe istraživanja postavljene su sledeće hipoteze:

1. Učenici srednjih škola svakodnevno koriste internet;

2. Učenici srednjih škola ne koriste internet za učenje engleskog jezika;

3. Nastavnici engleskog jezika u srednjim školama ne koriste internet kao nastavno sredstvo.

Istraživanje je realizovano tehnikom anketiranja. Korišten je deskriptivni metod. Konstruisan je upitnik koji sadrži 20 pitanja zatvorenog tipa. Korištena je Likertova skala sa ponuđenim odgovorima: „1. nikada”, „2. retko”, „3. često”, „4. svaki dan”, odnosno „1. nedovoljno”, ,2. malo i nedovoljno”, „3. malo ali dovoljno”, „4. dovoljno”. Statistička obrada podataka vršena je pomoću Microsoft Excel i SPSS.v2o paketa, pomoću kojih je obavljena statistička procedura izračunavanja srednje vrednosti u procentima. 
Ispitanici su učenici Gimnazije i tehničke škole „Kosovska Mitrovica”. Uzorak je nameran, jer su odeljenja pomenute srednje škole relativno malog obima, te da bismo bili sigurni da su obuhvaćeni učenici svih uzrasta i svih smerova, te različitih obrazovnih profila i iz različitih gradova kosovsko-mitrovačkog okruga. Ovime je, dakle, istraživanje obuhvatilo učenike ne samo sa teritorije grada Kosovske Mitrovice, već i one sa prebivališten u nekoj od okolnih opština (Zvečan, Zubin Potok, Vučitrn, Leposavić...).

\subsection{Nalazi i interpretacija}

U narednom delu rada predstavljeni su rezultati istraživanja sprovedenog među srednjoškolskom populacijom u Kosovskoj Mitrovici. Na osnovu testa samoprocene, dobili smo rezultate prikazane tabelama (Tabela 2, Tabela 3) i grafikonima (Prikaz 1, Prikaz 2, Prikaz 3).

Ispitivali smo korisnost interneta kada je u pitanju učenje i podučavanje, istraživali smo u kojoj meri i u koje svrhe učenici najčešće koriste internet i Jutjub, kao i na koji način (pomoću koliko i kojih uređaja) oni pristupaju internetu.

Istraživanje je pokazalo da većina učenika veruje da bi upotreba interneta u znatnoj meri olakšala usvajanje gradiva (pitanje br. 1), kao što se vidi iz priloženog (Prikaz 1).

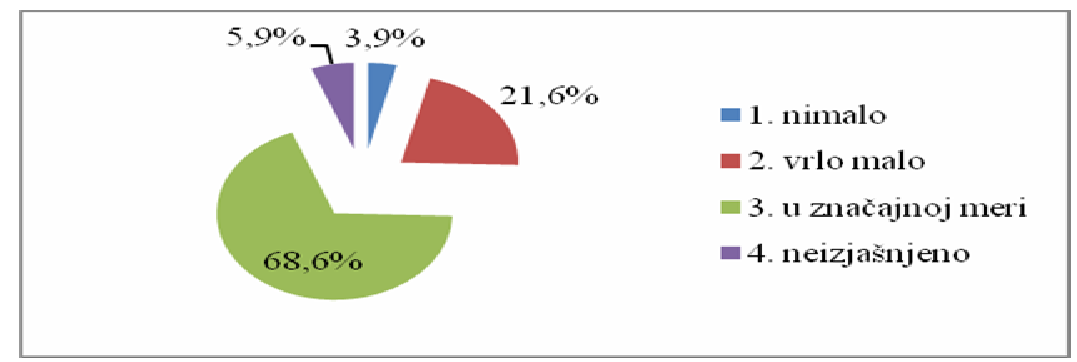

Prikaz 1. Stav ispitanika o tome da li bi upotreba interneta olakšala usvajanje gradiva

Ovo je za naš rad od velikog značaja jer potvrđuje aktuelnost teme i ukazuje na korisnost ovakvog istraživanja. Rezultati su sasvim očekivani imajući u vidu brojne prednosti interneta pomenute u prethodnom delu rada, kao i to koliko se učenici (i uopšte, adolescenti) oslanjaju na ovaj medij (Golijanin, 2014; Tapavički Duronjić, 2011; Arsović, prema Jovanović, 2014). Srednjoškolci su, možemo zaključiti, prepoznali „blagodeti” interneta (gotovo dve trećine učenika izjasnile su se na ovaj način) i u ovom svetlu bismo sugerisali da su se kod učenika možda već javila određena očekivanja što se tiče uvođenja interneta u nastavni i proces učenja. Svakako, ovo se ne odnosi se na sve učenike, budući da postoji i određeni (veoma mali) broj njih koji ne smatraju da bi internet na bilo koji način pomogao učenju.

Istraživanjem smo takođe želeli da otkrijemo u kojoj meri je ovaj medij dostupan učenicima odnosno, na koliko načina i pomoću kojih uređaja mu oni mogu pristupiti (pitanje br. 2). Prikazom 2 predstavljen je broj učenika koji poseduje jedan, odnosno dva, tri i četiri uređaja za pristup internetu. 


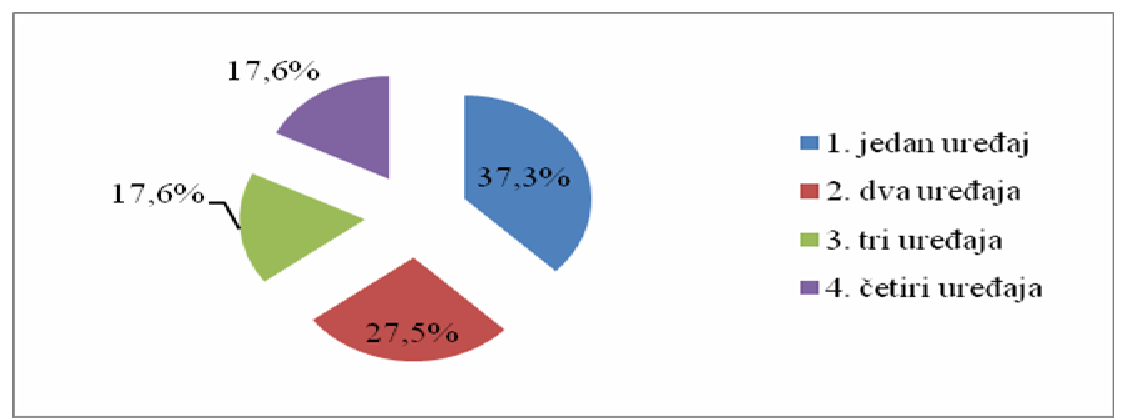

Prikaz 2. Broj uređaja za pristup internetu koje ispitanici poseduju

Uprkos tome što najveći broj ispitanika poseduje samo jedan uređaj pomoću koga pristupa internetu, broj onih koji imaju više ovakvih uređaja je daleko od zanemarljivog. Jasno je da je učenicima dostupnost ovog medija važna što je, opet, sasvim u skladu sa prethodno navedenim nalazima (Prikaz 1) i stavovima pomenutih autora, dok korišćenje većeg broja uređaja različite vrste (i stepena mobilnosti) nesumnjivo čini da je internet učenicima mnogo dostupniji. Da je ovo (dostupnost) za učenike zaista važno svojstvo, donekle potvrđuju i odgovori koje su dali na pitanje koji od navedenih uređaja najčešće koriste (Prikaz 3).

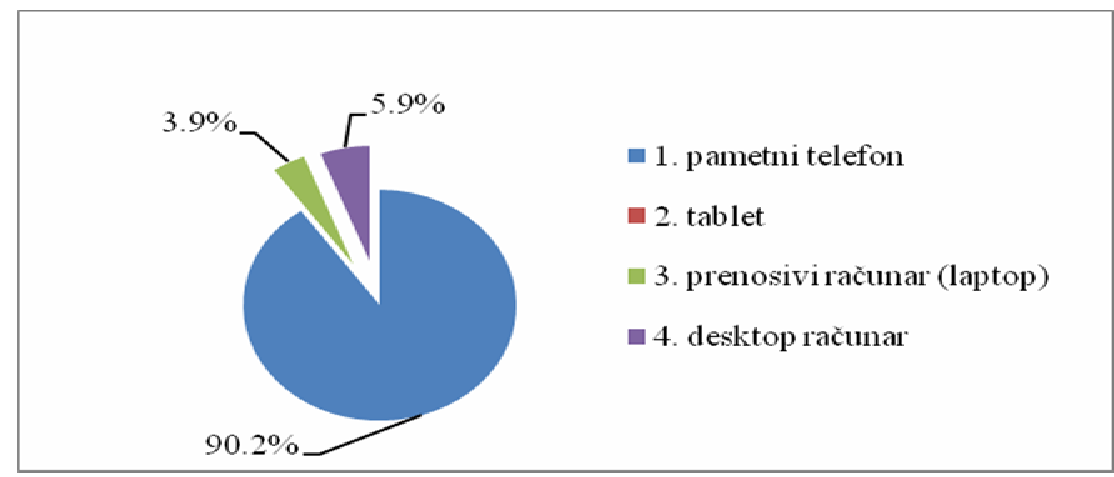

Prikaz 3. Vrsta uređaja koju ispitanici najčešće koriste za pristup internetu

Pametni telefon je očigledan izbor za net generaciju, kako ih naziva Golijanin, naviknutu na stalnu umreženost i slobodan pristup informacijama. Ovaj uređaj, za razliku od desktop računara, može da ,prati” korisnika, odnosno, kao i prenosivi računar i tablet, može se nositi bilo kuda. Ipak, očigledno je da mobilnost nije jedini razlog za popularnost pomenute vrste uređaja, budući da se drugi prenosivi uređaju (tablet i laptop) daleko ređe koriste. Zapravo, nakon pametnih telefona, najčešće korišten uređaj je desktop računar - koji je stacionaran, ali je daleko funkcionalniji od telefona, odnosno, pruža znatno više mogućnosti tokom korišćenja.

Zaključivši da se učenici upotrebom većeg broja uređaja na neki način staraju da uvek i svuda imaju pristup internetu, u Tabeli 2 pokazaćemo koliko i u koje svrhe srednjoškolci najčešće koriste internet. 
Tabela 2. Stepen i svrha korišćenja interneta od strane srednjoškolaca

\begin{tabular}{ccccc}
\hline RED. BR. & NIKADA & RETKO & ČESTO & SVAKI DAN \\
\hline 1. & $0,0 \%$ & $3,9 \%$ & $9,8 \%$ & $86,3 \%$ \\
\hline 2. & $0,0 \%$ & $9,8 \%$ & $31,4 \%$ & $58,8 \%$ \\
\hline 3. & $0,0 \%$ & $3,9 \%$ & $29,4 \%$ & $66,7 \%$ \\
\hline 4. & $11,8 \%$ & $21,6 \%$ & $33,3 \%$ & $33,3 \%$ \\
\hline 5. & $27,5 \%$ & $43,1 \%$ & $23,5 \%$ & $5,9 \%$ \\
\hline 6. & $31,4 \%$ & $37,3 \%$ & $7,8 \%$ & $23,5 \%$ \\
\hline 7. & $33,3 \%$ & $31,4 \%$ & $9,8 \%$ & $25,5 \%$ \\
\hline 8. & $13,7 \%$ & $27,5 \%$ & $27,5 \%$ & $31,4 \%$ \\
\hline 9. & $45,1 \%$ & $29,4 \%$ & $7,8 \%$ & $17,6 \%$ \\
\hline
\end{tabular}

Odgovori učenika na prvo pitanje (koje se tiče učestalosti upotrebe interneta), pokazuju da više od dve trećine učenika internet koriste svakodnevno (Tabela 2). Ovo ne treba da iznenađuje jer je, kako smo već naveli, brojnim autorima poput Tapavički Duronjić (2011), Golijanin i sar. (2014), Mandić (2003) i Eleven i Glušac (2008) ova zavisnost srednjoškolaca (i uopšte današnjih adolescenata kao pripadnika generacije Z, kako ih Tapavički Duronjić naziva), od računara i interneta i te kako poznata i razumljiva. Prema Tapavički Duronjić ovo bi se moglo objasniti činjenicom da su se pripadnici ove generacije rodili $u$ isto vreme kada su nastajale i „mašine kompjuteri” te je, moglo bi se reći, došlo do prvog „,bioničkog kontakta čoveka i mašine" (Tapavički Duronjić, 2011: 145). Ovim nalazima naša prva hipoteza je nedvosmisleno potvrđena.

Iz odgovora učenika na 2. pitanje (koje se tiče učestalosti upotrebe Jutjuba) vidimo da oni u velikoj meri koriste i ovaj veoma popularan veb-sajt. Svakodnevno ga koristi više od polovine učenika. Mišljenja smo da je razlog tome priroda sadržaja koje Jutjub veb-sajt nudi, odnosno, to što video-forma odgovara generaciji koja, kako ukazuje Mandić (2009), preferira multimedijalni prikaz informacija u odnosu na klasični (samo vizuelni ili samo zvučni) prikaz istih.

Naredna pitanja (3-9), odnose se na svrhu upotrebe interneta i Jutjuba od strane ispitanika. Pokazalo se da srednjoškolci ova dva medija koriste pre svega za zabavu i informisanje (pitanje br. 3), te ih većina učenika svakodnevno koristi za slušanje muzike, gledanje filmova/serija, itd. Pitanja broj 4, 5, 6, i 7. ispituju da li, i u kojoj meri, učenici koriste ove medije za učenje/obnavljanje školskog gradiva, te za učenje jezika kakav je engleski jezik. Iz Tabele 2 vidi se da učestalost korišćenja ovih medija znatno opada kada je u pitanju njhova upotreba u edukativne svrhe. Tako, na primer, učenici znatno ređe na internetu pretražuju edukativne i informativne sadržaje poput dokumentarnih filmova, tutorijala, uradi-sam videa (pitanje br. 4); svakodnevno ovo čini manje od polovine učenika, a pojedini učenici nikada. Za pronalaženje lekcija vezanih za gradivo u školi (pitanje br. 5), internet se takođe malo i retko koristi. Ipak, treba imati u vidu da se ovo nipošto ne može pripisati nedovoljnoj količini informacija koje se čuvaju na internetu, znajući da on predstavlja pre svega jednu bogatu bazu znanja (Klarić, 2009). Postoji mogućnost da je slaba zainteresovanost đaka za školsko gradivo ili ovu vrstu tehnologije uzrok ovakve situacije. Još jedan mogući uzrok bila bi nedovoljno razvijena svest o edukativnom potencijalu interneta. Kada je u pitanju upotreba interneta za učenje stranih (pitanje br. 6), a naročito, engleskog jezika (pitanje br 7), pokazalo se da većina učenika to čini 
retko ili nikada, što potvrđuje našu drugu hipotezu. No, približno jedna četvrtina učenika se izjasnila da to čini svakodnevno, što bismo mogli objasniti ličnim afinitetom ili motivacijom učenika za učenje stranog, a pre svega engleskog jezika.

Iz odgovora učenika na 8. pitanje - „da li koristite Jutjub da gledate muzičke spotove, sport, filmove/isečke iz filmova, vesti na engleskom jeziku sa ciljem učenja jezika" - primećujemo da se učenici sve češće opredeljuju za manje formalne metode učenja jezika poput gledanja sportskih, informativnih i edukativnih sadržaja (tutorijala, dokumentarnih filmova, uradi-sam videa) na engleskom jeziku koji nisu direktno usmereni na učenje i razumevanje jezika, ali i te kako pomažu usavršavanje jezika kod učenika. Ovo bi se moglo opet dovesti u vezu sa manjkom interesovanja za učenje jezika koje se kod pojedinih ispitanika ispoljava nedostatkom motivacije za formalni vid učenja jezika, te se pribegava nekoj vrsti posrednog „usvajanja” jezičke kompetencije kroz njima interesantne sadržaje.

Pitanje br. 9 - „da li koristite Jutjub veb-sajt za učenje engleske gramatike i engleskog vokabulara" - pokazalo je da gotovo polovina ispitanih učenika Jutjub nikada nije upotrebila u svrhu ovladavanja ovim jezičkim sistemima. Određeni broj učenika se ipak izjasnio da to čini svakodnevno, kao što se vidi u Tabeli 2.

Kako cilj rada nije samo da ustanovi stepen korišćenja interneta kao važnog segmenta IKT-a u učenju engleskog jezika, istraživanjem smo nastojali i da ispitamo meru u kojoj se internet koristi u nastavi ovog jezika (Tabela 3).

Tabela 3. Stepen i svrha korišćenja interneta kao nastavnog sredstva na nivou srednje škole

RED. NEDOVOLJNO MALO INEDOVOLJNO MALO ALI DOVOLJNO DOVOLJNO
BR.

\begin{tabular}{|c|c|c|c|c|}
\hline 1. & $25,5 \%$ & $17,6 \%$ & $33,3 \%$ & $23,5 \%$ \\
\hline 2. & $47,1 \%$ & $15,7 \%$ & $19,6 \%$ & $17,6 \%$ \\
\hline 3. & $58,8 \%$ & $17,6 \%$ & $7,8 \%$ & $15,7 \%$ \\
\hline 4. & $60,8 \%$ & $15,7 \%$ & $7,8 \%$ & $15,7 \%$ \\
\hline 5. & $56,9 \%$ & $17,6 \%$ & $15,7 \%$ & $9,8 \%$ \\
\hline 6. & $56,9 \%$ & $19,6 \%$ & $7,8 \%$ & $15,7 \%$ \\
\hline 7. & $60,8 \%$ & $15,7 \%$ & $13,7 \%$ & $9,8 \%$ \\
\hline
\end{tabular}

Posmatrajući Tabelu 3, zaključujemo da se internet kao nastavno sredstvo u ovoj školi ipak koristi. Učenici su, sudeći prema rezultatima istraživanja, i te kako svesni činjenice da bi internet u nastavi trebalo upotrebljavati daleko više. Međutim, određeni broj učenika je zadovoljan i sadašnjim stanjem izjašnjavajući se, shodno tome, da se internet u nastavi ipak koristi dovoljno, odnosno malo ali dovoljno (što se može videti kod pitanja br. 1 - „da li nastavnici koriste internet u toku časa kao nastavno sredstvo"). Ovim je naša treća hipoteza, kojom se pretpostavlja da se internet i Jutjub u nastavi uopšte ne koriste, opovrgnuta. Pomenuti stav nekolicine učenika da se internet ipak dovoljno, odnosno malo ali dovoljno koristi nije sasvim zanemarljiv, uprkos maloj procentualnoj vrednosti. Ovo se može objasniti i razlikama među odeljenjima, u nekima od kojih broj učenika ne premašuje 10. Moguće je, iako 
se ne može se sa sigurnošću tvrditi, da su u pitanju učenici jednog odeljenja čiji nastavnik zaista koristi internet i/ili Jutjub češće od ostalih nastavnika.

Iz pitanja broj 2, vidimo da je utisak ispitanika da nastavnici engleskog jezika u nešto manjoj meri koriste ove medije. Ponovo se javlja određeni broj učenika koji smatra da se internet kao nastavno sredstvo dovoljno koristi, što bismo opet doveli u vezu sa razlikama među odeljenjima. Nastavnici, takođe, retko pojašnjavaju gradivo koristeći internet, vidi se iz pitanja broj 3 u Tabeli 3. Jedan od najčešćih razloga za ovo je nedostatak kompetencije nastavnika, o čemu su govorili Danilović i Danilović (2012), Stanković (2012) i Mandić, citiran u Petrović (2016). Mnogi nastavnici zaziru od upotrebe novih tehnologija podjednako koliko i od učenja o njima. Ovaj se utisak potvrđuje i kada se analiziraju odgovori na preostala pitanja izložena u tabeli. Nastavnici engleskog jezika nedovoljno koriste internet za predstavljanje engleske gramatike i vokabulara (pitanje br. 4), nedovoljno koriste Jutjub kao nastavno sredstvo (pitanje br. 5) i nedovoljno puštaju muzičke spotove, sport, filmove/isečke iz filmova, vesti na engleskom jeziku. Češće, ali još uvek u nedovoljnoj meri, nastavnici puštaju ovakve sadržaje na srpskom jeziku. Iz ovoga bi se moglo zaključiti da nastavnici nastoje na istovremenom razvijanju interkulturoloških i jezičkih kompetencija učenika. Osim nekolicine posebnih slučajeva, istraživanje pokazuje da se internet i Jutjub u nastavi engleskog jezika na srednjoškolskom nivou vrlo malo koriste. No, uprkos tome, oni se među ispitanicima i dalje smatraju korisnim sredstvom za učenje i podučavanje. Ovakvo opredeljivanje net generacije za nastavu obogaćenu IKT-om je svakako očekivano, i uz to, ohrabrujuće, budući da može dodatno ubrzati implementaciju IKT-a u nastavni i obrazovni proces. Ipak, svemu ovome se mora ozbiljno pristupiti, počevši od podizanja svesti nastavnika i učenika o korisnosti ovih tehnologija, a pre svega interneta kao važnog njihovog segmenta, preko osposobljavanja nastavnog kadra, pa sve do prevazilaženja bezbednosnih problema i obezbeđivanja neophodne opreme za škole.

\section{ZAKLUČAK}

Na osnovu svega dosad navedenog, zaključujemo da je potencijal interneta kao segmenta informaciono-komunikacionih tehnologija izuzetan. Ovaj je potencijal već prepoznat u svetu, a postepeno se i u našoj zemlji korača u pravcu integrisanja ovih tehnologija u obrazovni sistem.

Istraživanje je pokazalo da se na nivou srednje škole internet u nastavi još uvek nedovoljno koristi, premda ga sami učenici koriste na svakodnevnom nivou, što je u skladu sa našom prvom polaznom pretpostavkom. Nažalost, pokazalo se oni internet koriste uglavnom za razonodu i informisanje o njima važnim stvarima, a znatno manje za učenje i obnavljanje školskog gradiva. Ovo je donekle u skladu sa našom drugom pretpostavkom da učenici ne koriste ni internet niti Jutjub u obrazovne svrhe. lako ispitanici ređe biraju internet kao sredstvo za ovladavanje znanjima, oni se ipak u znatnoj meri oslanjaju na ovaj medij kada je u pitanju učenje engleskog jezika, iako u tom slučaju biraju manje formalne načine učenja. Dok se video lekcije, edukativni i informativni sadržaji na internetu i Jutjub video-materijali za savladavanje engleskog vokabulara i gramatike prate vrlo retko, radije se i češće gledaju i pretražuju zabavni i sportski sadržaji na engleskom jeziku, na koji način učenici usvajaju jezik.

Kako smatra većina ispitanika, internet se još uvek u nastavi ne koristi u punoj meri. Što se tiče korišćenja ovog medija sa ciljem učenja engleskog jezika, ovladavanja engleskom gramatikom i vokabularom i, uopšte, neophodnim jezičkim veštinama, većina učenika nema priliku da na 
času uči jezik na ovaj način; retko to čine i van škole, ali ipak smatraju da bi se na ovaj način umnogome olakšao proces učenja školskog gradiva.

Ostaje nam da zaključimo da bi u budućnosti trebalo ozbiljnije poraditi na integraciji ovog izuzetno korisnog medija u nastavni i proces učenja. Nastavnici, učenici, profesori, studenti i njihovi rukovodioci treba zajedno da se založe za ubrzanje ove integracije, koja bi, uvereni smo, bila od koristi i njima i njihovim profesorima.

\section{Literatura}

Ahmadi, D. M. R. (2018). The Use of Technology in English Language Learning: A Literature Review. IJREE. Preuzeto 28. 10. 2019. sa: http://ijreeonline.com/article-1-120-en.html.

Bascom, J. (1907). Is Language a Living Thing? The Pedagogical Seminary, 14(1), 117-120. DOI: 10.1080/08919402.1907.10534379.

Bhakta, K., \& Dutta, N. (2016). Impact of Information Technology on Teaching-Learning Process, International Research Journal of Interdisciplinary \& Multidisciplinary Studies (IRJIMS). 2 (11), 131-138. Preuzeto 24. 11. 2019. sa: http://www.irjims.com.

Commission of the European Communities (2008). The use of ICT to support innovation and lifelong learning for all: A report on progress. SEC. 2629. Preuzeto 10. 10. 2019. sa: http://www.europarl.europa.eu/registre/docs_autres_institutions/commission_europe enne/sec/2008/2629/COM SEC(2008)2629 EN.pdf.

Danilović, M., Danilović, P. (2012). Problemi određivanja značenja i definisanja pojmova „informaciona“, „informatička“, „,informaciono-komunikaciona“, „informaciono kompjuterska“" obrazovna tehnika i tehnologija, Tehnika i informatika u obrazovanju, 4. Internacionalna konferencija, Čačak: Tehnički fakultet Čačak.

Dresel, M., \& Händel, M. (2008). A Computer-Based Approach to Fostering Motivation and Self-Regulated Learning, Journal of Experimental Education - J EXP EDUC. 77. 3-20. DOI: 10.3200/JEXE.77.1.3-20.

Eleven, E. i Glušac, G. (2008). Učenje na daljinu - dopuna ili deo savremene nastave. U D. Golubović, (Ur.), Tehnika i informatika u obrazovanju (str. 397-402). Čačak: Tehnički fakultet Čačak;

Golijanin, D., Miljković, M., Alčaković, S., Gavrilović, J., Savković, M., Stamenković, D. (2014). Generacija Z, internet i obrazovanje, Sinteza, Internet and education. 506-509. DOI: 10.15308/SInteZa-2014-506-509.

Harmer, J. (2007). The Practice of English Language Teaching. Harlow: Longman.

Jovanović, S. (2010). Novi mediji-individualizacija i diferencijacija nastave likovne kulture. Neobjavljen magistarski rad. Sombor: Pedagoški fakultet.

Jovanović, S. (2014). Kompetencije i uloge učitelja u skladu sa dostignućima informaciono komunikacionih tehnologija i novim paradigmama obrazovanja. Zbornik VŠsSOV. Kikinda: VŠSS, 9(1), 111-124.

Kern, N. (2013). Technology-integrated English for Specific Purposes lessons: real-life language, tasks and tools for professionals. U G. Motteram (Ur.), Innovations in learning technologies for English language learning (pp. 87-115). London: British Council.

Klarić, N. (2009). Primjena savremenih sredstava informacionih tehnologija u obrazovnim procesima. Specijalistički rad. Banja Luka: Apeiron.

Klimova, B. F. (2012). ICT versus traditional approaches to teaching, Procedia - Social and Behavioral Sciences, 47 (2012), 196-200. Preuzeto 22. 11. 2019. sa: 
https://www.researchgate.net/publication/257716276 ICT_Versus_Traditional_Approa ches to Teaching.

Krashen, S. (1987). Principles and practice in second language acquisition. New Jersey: Englewood Cliffs, N. J., Prentice-Hall.

Krželj, K. i Polovina, N. (2019). Značaj ključnih kompetencija iz perspektive nastavnika stranih jezika, Andragoške studije, 1, 111-134.

Lance, J., \& Kitchin, P. J. (2007). Promoting the individual learning styles of Masters Students studying marketing- related modules through the use of YouTube video-clips. Investigations in University Teaching and Learning. Preuzeto 15. 10. 2019. sa https://www.researchgate.net/publication/228770390.

Lončarić, D. (2014). Motivacija i strategije samoregulacije učenja: teorija, mjerenje i primjena. Učiteljski fakultet u Rijeci. ISBN 978-953-7917-03-6.

Maksimović, J. (2012). Teorijski, saznajni i praktični aspekti metodološkog i statističkog usavršavanja nastavnika, Istraživanja u pedagogiji, 2(1), 11-28. Preuzeto 2. 12. 2019. ca: http://www.uskolavrsac.edu.rs/wp-content/uploads/2011/06/Istrazivanja-u-pedagogijibr-2.pdf.

Mandić, D. (2003). Didaktičko-informatičke inovacije u nastavi. Beograd: Mediagraf.

Mandić, D. (2009). Obrazovanje na daljinu. Preuzeto 18. 10. 2019. sa https://www.academia.edu/7132774/dr_Danimir_Mandi\%C4\%87_OBRAZOVANJE_NA_D ALJINU.

Marković Blagojević, M., Aćimović, S. i Karavelić, D., (2017). Uticaj informacionokomunikacionih tehnologija na unapređenje kompetencija i veština nastavnog kadra, Ekonomija: teorija i praksa, 10 (2), 52-65.

Milošević, H., Kontrec, N. i Đošić, D. (2013). Veštine komuniciranja. Beograd: Prirodnomatematički fakultet Univerziteta u Prištini.

Montero, R. L. (2018). Anxiety and foreign language learning for young adolescents. Wimblu, Rev. Estud. Esc. de Psicología UCR, 13(1), 63-77.

Nadrljanski, Đ. (2006). Informatička pismenost i informatizacija obrazovanja, Informatologija, $39,262-266$.

NPS (2013). Smernice za unapređivanje uloge informaciono-komunikacionih tehnologija u obrazovanju. Beograd: Nacionalni prosvetni savet Republike Srbije. Preuzeto 12. 10. 2019. sa: https://www.cipcentar.org/i_roditelji_se_pitaju/PDF/strategija/Smernice IKT.pdf.

Nunan, D. (2003). Practical English Language Teaching. McGraw-Hill: Singapore.

Passey, D., Rogers, C., Machell, J., \& McHugh, G. (2004). The Motivational Effect of ICT on Pupils. Preuzeto 20. 11. 2019. sa: http://downloads01.smarttech.com/media/research/international research/uk.

Petrović, M. (2016). Model e-učenja za podršku razvoju informatičkih kompetencija zaposlenih u obrazovanju. Doktorski rad. Novi Sad: Prirodno-matematički fakultet. Preuzeto 20. 10. 2019. sa: http://nardus.mpn.gov.rs/bitstream/handle/123456789/7184/.

Pintrich, P. R. (1995). Understanding self-regulated learning, New Directions for Teaching and Learning, 63, 3-12. Jossey-Bass.

Radić Branisavljević, M. i Milovanović, M. (2014). Savremene tehnologije u nastavi stranih jezika, Sinteza, 500-505. Singidunum University, Serbia. DOI: 10.15308/SInteZa-2014500-505.

Ranđelović, M. (2018). Digitalni dijalog kao reinženjering u sistemu hibridnog učenja. Doktorska disertacija. Čačak: Univerzitet u Kragujevcu, Fakultet tehničkih nauka u Čačku. 
Stanković, Z. (2012). Obrazovna tehnologija - potreba i neminovnost savremenog univerzitetskog obrazovanja. U B. Dimitrijević (Ur.), Obrazovanje i savremeni univerzitet (str. 155-164). Niš: Filozofski fakultet Univerziteta u Nišu.

Strategija razvoja obrazovanja u Srbiji do 2020. Godine (2012). Službeni glasnik RS, br. 107/2012 od 9. 11. 2012. godine. Preuzeto 15. 10. 2019. sa: http://www.mpn.gov.rs/wpcontent/uploads/2015/08/STRATEGIJA-OBRAZOVANJA.pdf.

Tapavički Duronjić, T. (2011). Postmilenijumska generacija u umnoženoj stvarnosti. Kultura polisa, 2011. Preuzeto 18. 10. 2019. sa http://kpolisa.com/KP16/kp16-III-2TatjanaTapavickiDuronjic.pdf?fbclid=IwAR3SD7rY1UQrUBZeMwmrpNe\%20EPSeVzqxqC k24UK6mnON5HF1cq9y5mqtg.

Vasić, M. (2010). Šta je to internet - Tehnološke osnove interneta, Etnoantropološke sveske, 5, 79-93. Preuzeto 16. 10. 2019. sa https://www.researchgate.net/publication/262395884.

\section{Biografske note}

Katarina Savković je diplomirala je na odseku za Engleski jezik i književnost 2018. godine sa prosečnom ocenom 9,57. Diplomske akademske master studije završila je 2019. godine, takođe na Filozofskom fakultetu u Kosovskoj Mitrovici sa prosečnom ocenom 9,83. Od oktobra 2019. ima status studenta doktorskih studija. Za vreme osnovnih studija bila je stipendista Republike Srbije za izuzetno nadarene studente (2016-2017), a na završnoj godini osnovnih studija - stipendista Fonda za mlade talente Republike Srbije za najbolje studente završnih godina (2018). Tokom osnovnih akademskih studija na Filozofskom fakultetu bila je angažovana kao student-demonstrator na predmetima Sintaksa 1 i Sintaksa 2 (2017-2019).

Nikola Vasić završio je osnovne akademske studije 2018. godine na Prirodno-matematičkom fakultetu Univerziteta u Prištini sa sedištem u Kosovskoj Mitrovici na Katedri za informatiku. Master akademske studije završio je na istom fakultetu 2019. godine sa prosečnom ocenom 9,67. Školske 2019/2020. godine upisao je doktorske akademske studije na Elektronskom fakultetu Univerziteta u Nišu na modulu Računarstvo i Informatika. Od marta 2019. angažovan je kao saradnik u nastavi na Visokoj tehničkoj školi strukovnih studija u Nišu. 